\title{
Neglected Outcomes of Customer Orientation in Urban Public Water Utilities in Uganda and Tanzania
}

\author{
Mukokoma M. M. N. ${ }^{1, *}$, Ssemwogere E. ${ }^{1}$
}

(C) Uganda Martyrs University

\begin{abstract}
We used 30 decision making units (DMUs) of National Water and Sewerage Corporation (NWSC) in Uganda and Dar es Salaam Water and Sewerage Corporation [DAWASCO] in Tanzania to collect data from customers and workers/regulators of the two utilities. We also collected secondary data on the performance of the utilities in 2010. We used this data to calculate the Data Envelopment Analysis (DEA) for the DMUs. The results indicate high adoption of customer orientation in NWCS' DMUs (mean score $=86 \%$ ) while in DAWASCO's DMUs the mean score is $44 \%$. The results from DEA analysis show a mean efficiency score of $93 \%$ for NWSC and $71 \%$ for DAWASCO. Also, the findings indicate a service quality gap of -1.98 for NWSC and -2.81 for DAWASCO. We found that there is a positive correlation between customer orientation and efficiency $(0.58[\mathrm{p}<0.01])$; a positive correlation between customer orientation and customer satisfaction $(0.36$ [ $p>0.01])$; and an inverse correlation between customer satisfaction and efficiency $(0.043 \%$ [p $>0.01])$. These results imply that increased adoption of customer orientation reforms enhances technical efficiency albeit the resultant improvement in customer satisfaction is statistically insignificant.
\end{abstract}

Keywords $\cdot$ Customer orientation $\cdot$ Service quality $\cdot$ DEA

\section{Introduction}

Water service delivery is essential to public health, economic development and the state of the environment (Shi, 2002). It is therefore important to assess how efficiently a water utility delivers its services and whether customers are satisfied with the quality of water service delivery. With the reforms that are taking place in the water sector, the customer of water is now playing a centre stage in urban water service delivery (OECD 2003, Ogawa and Tanattashi 2008). Thus, customers assess the quality of service accorded and decide whether it meets his/her expectations (Parasuraman et. al 1985; 1988). Using 30 DMUs of National Water and Sewerage Corporation (NWSC) for Uganda, and Dar Es Salaam Water and Sewerage Corporation (DAWASCO) for Tanzania, we empirically

\footnotetext{
${ }^{1}$ Uganda Martyrs University.*Corresponding author: mnalwoga@umu.ac.ug.
} 
assess the level of customer orientation, technical efficiency and customer satisfaction with urban water service delivery quality. We also attempt to assess the relationship between customer orientation, technical efficiency, and customer satisfaction with the service quality. In this paper we explain the background of water service delivery reforms in NWSC and DAWASCO, review literature on customer orientation, efficiency and customer satisfactions with water service delivery, describe the approach and method and discuss the empirical findings.

\section{Reforms in NWSC and DAWASCO}

NWSC, established in 1972, is a public Corporation wholly owned by the Government of Uganda as the principal provider of water services in the large urban centres of Uganda currently operating in 23 towns.

The external structural and legal reforms of NWSC date way back to 1995 when the utility was re-established as a corporation by the NWSC Act. However, despite the structural and legal reforms, water service delivery remained very poor characterized by unreliable water supply, low service coverage, inefficient billing and collection practices, inaccessibility of water especially in poor urban settings, aged and poorly maintained water infrastructure and generally very poor financial performance (MWLE, 1998). Because of these water service delivery problems, government, together with donors were convinced that an international private operator was the solution. Consequently, in 1999 government through the Ministry of Water told the management of the corporation that the later will be privatized if performance does not improve. The privatization threat triggered management of NWSC to adopt NPM reforms of segmentation of functions, autonomy of units (towns), market orientation, customer orientation, and output orientation and accountability (Muhairwe, 2009).

Until the late 1970s, Dar city's water supply more or less kept pace with the rate of population growth with the government policy of "free water for all". Eventually the availability and quality of water supply started declining. Between 1977 and 1997 per capita consumption on households with piped water connections dropped by $50 \%$ in upmarket Oyster Bay and by nearly 75\% in low-income Temeke. By 1997, the proportion of customers receiving mains water who enjoyed uninterrupted supply fell from $100 \%$ to $27 \%$. By 2003 only $25 \%$ of the water being sourced was reaching legally connected consumers due to leakages and illegal connections. Not more than $16 \%$ of the water produced was being paid for and over $60 \%$ of the water urban poor have no direct access to piped network (Water Aid, 2005). The declining services resulted from poor maintenance and lack of investment in the face of increasing demand from the growing population.

Part of the strategy to improve the performance of the sector was to create a semiautonomous Dar es Salaam Water and Sewerage Authority (DAWASA) and 18 Urban Water and Sewerage Authorities (UWASA) in 1997. As "authorities", these institutions were institutionally and financially autonomous.

DAWASA proved to be no better than its predecessor, and the wastage and disrepair reached crisis levels. The water system had failed to keep up with population growth in the city, and by 2003 only 98,000 households in a city of over 2.5 million people had a direct water connection (Water Aid Tanzania, 2003). By then, only $26 \%$ of water was being billed, $60 \%$ was lost through leaks, and a further $14 \%$ through unauthorised use, illegal taps and non-payers. Even those with connections only received water irregularly, and the 
water quality was poor. In low income areas, the vast majority of households had no water connection at all, relying instead on buying water from kiosks, water vendors or their neighbours, at more than three times the price (Water Aid Tanzania, 2003). Results from the Policy and Satisfaction Survey research on Poverty alleviation in 2003 indicated that more than $40 \%$ of households in Dar considered domestic water supply a 'major problem'.

To improve water service delivery various stakeholders particularly the World Bank and Donors pressed for the privatization of DAWASA. In 1997, the privatization of DAWASA was launched and finalized in early 2003 when a 10 year lease contract was signed with City Water (a joint venture owned by British Biwater International, German Gauff Ingenieure, and Tanzanian Super doll Trailer Manufacture). Unfortunately, in May 2005 the contract of City Water was cancelled for allegedly breach of contract and poor performance. After the cancellation, operations were handed over to DAWASCO. DAWASCO is publicly owned though expected to operate with a commercial orientation. As per Water sector report of 2009, DAWASCO has 153,614 connections, metering efficiency of $48 \%$, and NRW of 55\%. In what can be viewed as East African Cooperation, DAWASCO has been getting technical assistance from NWSC of Uganda.

\section{Related Literature}

In this sub unit we review literature on customer orientation, efficiency, and customer satisfaction with urban water service delivery.

\section{Customer Orientation}

Many performance measurements are connected with the reform initiative to increase customer orientation in water service delivery. Customer orientation is a foreign term in the vocabulary of public utilities. Most utilities portray a service based (as opposed to a customer based) culture. Since the government was the major funder, all attention was addressed to fulfilling government requirements as opposed to customer satisfaction. With the New Public Management reforms, focus is on recovering service provision costs from the customer. Indeed there is a connection between increasing the utility's income from user fees and the necessity to improve customer orientation (Awortwi, 2003).

Different terms are used to refer to the consumer of a public service. These include: citizens, clients, and customers. Although in a strict sense these terms have different meanings, in this context they more or less appear interchangeable. The variety of terms used can partly be a result of the different public service orientations of the authors. For example, the beneficiary of a road service would not be referred to as a customer while this can be the case for water services.

\section{Understanding Customer Orientation}

Customer orientation has been defined differently by different researchers. Kotler (1987 p.41) defines it as a process of ensuring that "the main task of the organization is to determine the perceptions, needs, and wants of the target market and to satisfy them through the design, communication, pricing, and delivery of appropriate and competitive viable offers". On the other hand, Perreault and MacCarth (1990) define customer orientation as an organizational culture where everyone in a firm works together to satisfy customer needs at a profit. 
Kohli and Jaworsk (1990) explain customer orientation as a sub-set of market orientation. To the researchers market orientation has three major components, namely: 1 . One or more departments engaging in activities geared toward developing and understanding of customer's current and future needs and the factors affecting them; 2.sharing this understanding across departments; 3. Departments engaging in activities designed to meet customer needs. Also Narver and Slater (1990) explain market orientation as consisting of three behavioural components, thus; customer orientation, competitor orientation and inter-functional coordination.

Clearly, some researchers view customer orientation as a sub-set of market orientation. In this research we consider the two separately. We define customer orientation as involving intelligence gathering, intelligence dissemination and the DMU's responsiveness to customer needs and expectations.

The customer orientation focus has changed water utility orientation from being government and management oriented to being customer oriented as shown in Figures 1a and $b$.
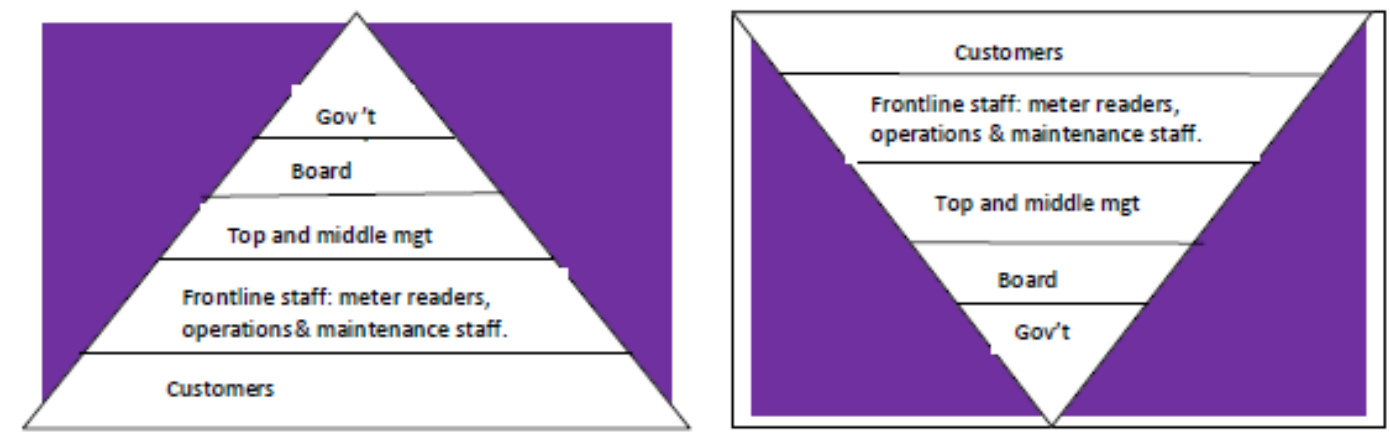

Figure 1.a Government \& management oriented utility Figure 1. b Customer oriented utility Source: Adopted from Doyle (1994) cited Wilson and Gilligan (1997)

Empirical research conducted in service management has shown that customer orientation leads to customer satisfaction and consequently higher profitability (Jaworsk and Kohli, 1993; Slater and Narver, 1995). Customer orientation has become a key organizational strategy. Jaworsk and Kohli (1993) proposed a model to measure customer orientation. The model includes three components: intelligence generation, intelligence dissemination, and organizational wise responsiveness. Dulaiman (2005) urges that if this model is applied to an organization it should be able to satisfy customer needs and expectations. The author further contends that the use of the term market orientation in explaining customer orientation is useful to make it clear that the latter is much broader that establishment of customer needs and expectations. The researcher suggests that the two terms can be used interchangeably. Intelligence generation means collection of information about the needs and expectations of customers. The effectiveness of intelligence generation is influenced by who collects the intelligence, how the information is captured and the frequency of collecting information. Intelligence dissemination in an organization can be evaluated by analyzing the process of distributing knowledge within the organisation

The concept of customer orientation has started to take root in the water sector. This concept is of particular relevance to the urban water sector given that household consumers get water from various providers and sources. Across any one city private vendors, individual household on-selling, family and institutional boreholes, hand dug 
wells, springs, streams and rain water support the market for water. These alternative supplies that often supplement, replace or substitute direct utility provided water are accessed through informal human and physical networks. Although often unregulated, unreliable and costly, people use them regularly either through necessity or choice.

Customer orientation has led to increasing customer pressure and the evaluation of the performance of water service providers so as to improve service quality (Bovaird, 2006). Indeed there is a link between customer orientation and well performing utilities (Yepes, 1990; Van Dijk, 2006). Customer orientation is also related to increased accountability to consumers (Batley, 1999).

\section{Efficiency}

Efficiency measurement is based on the production theory that views a firm as a production system where input resources utilized by the firm are translated into desirable outputs. Common tools used to measure efficiency are ratio analysis and frontier techniques. Ratio analysis involves a comparison between inputs and outputs. Simple ratios like staff per connection, water delivered per staff and operating cost per connection among others, are commonly used in the water sector as indicated by Tynan and Kingdom (2002). These are single - measure gap analysis that involve use of separate efficiency indicators like staff per 1000 connections, and expenditure as a percentage of revenue generated. Frontier analysis is a tool used to benchmark the relative performance of Decision Making Units (DMUs) by assessing how close the DMUs are to a "best practice" frontier as explained by Farrell 1957. A common method used is Data Envelopment Analysis (DEA).

DEA is a non-parametric method that was first introduced in 1978 by Charnes et al. 1978 as an empirically based methodology that eliminates the need for some of the assumptions and limitations of traditional efficiency measurement approaches. Many researchers like, Thanassoulis et al. 2000; Kirkpatrick et al. 2006; Ogawa and Tanashi, 2008; and Ndandiko, 2010 have used DEA to assess efficiency of government service providers. Attractions to using DEA as a performance measurement models include the ability to handle multiple inputs and outputs, and ability to identify possible benchmarks.

\section{Customer Satisfaction}

Customer satisfaction is an abstract concept and its actual manifestation varies. Consequently, researchers conceptualise it differently (Oliver 1981; Parasuramann et al. 1985, Brady and Robertson 2001; Kaplan 2005; Benington 2007). A common understanding is viewing it as an individual's feeling of pleasure or disappointment resulting from comparing a product's or service's perceived performance (outcome) in relation to his or her expectations. Work done by Parasuraman et al. between 1985 and 1988 provides a basis for this common understanding by using a gap between the customer's expectation and their perceived experience of performance.

Moore (1995) argues that to measure customer satisfaction, it is important to define who the customer of a water utility is. Moore (1995:8) defines the customer of a water utility as "the person who engages in a transaction at the business end of the organization". Measuring customer satisfaction is vital because customers have rights (access to safe, clean and affordable water) that need to be protected in the delivery of water services.

Parasuraman et al. (1985) developed an instrument to measure service quality generally known as SERVQUAL. The disconfirmation paradigm is the basis of the SERVQUAL 
model, which views service quality as the gap between the expected level of service and the customer perceptions of the level received. It is this SERVQUAL instrument that we use to assess the quality of urban water service delivery and consequently customer satisfaction in Uganda and Tanzania.

\section{Understanding Service quality}

Lewis, (1993) describes service quality as a measure of how well the service level delivered matches customers' expectations. Bitner et al. (1994.97) define it as, "the consumer's overall impression of the relative inferiority or superiority of the organization and its services". Cronin and Taylor (1992) on the other hand view service quality as a form of attitude representing a long-run overall evaluation. Also Parasuraman et al. (1985: 48) define service quality as "a function of the differences between expectation and performance along the quality dimensions". Thus the customer is essential in defining service quality.

Water service quality can be described in terms of objective and subjective characteristics. Objective characteristics include time water is available in a day, call wait time, time taken to respond to customer complaint, number of complaints, and distance to water point. Perceptual characteristics on the other hand depend on the customer's perceptions which include dimensions of reliability, responsiveness, tangibles, assurance and empathy as shown in Table 2. This research is focusing on the perceptual characteristics as reliable data on objective measure was difficult to obtain.

\section{Dimensions of Service Quality}

The instrument has five dimensions as shown in Figure 2 below.

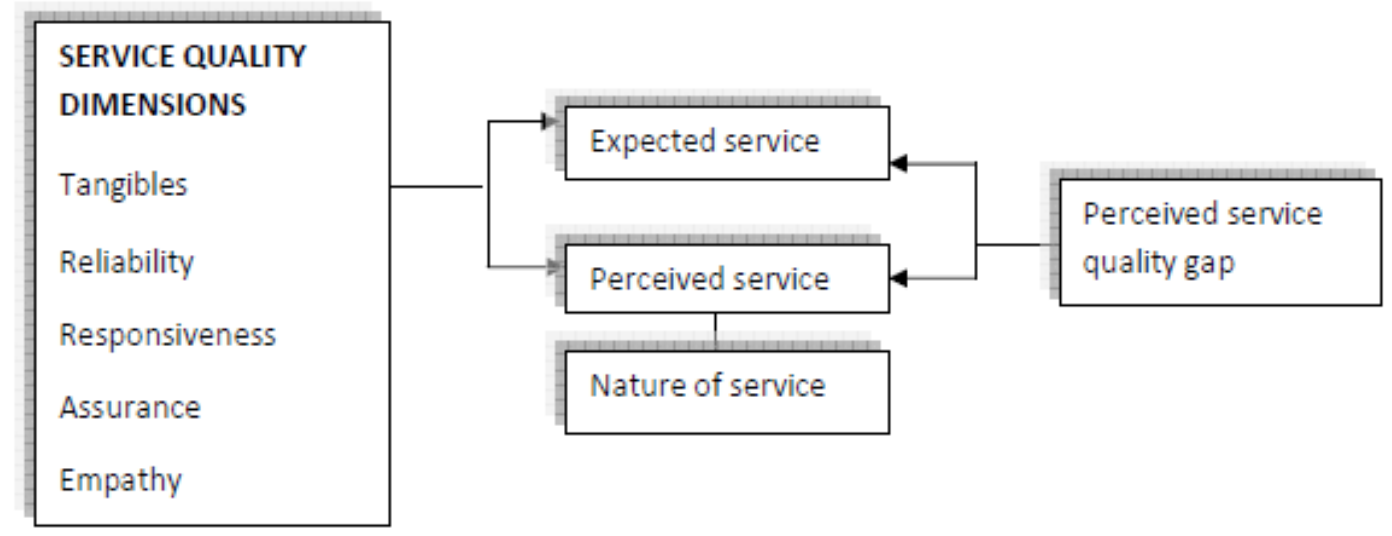

Figure 2: Perceived Service Quality Gap

Source: adapted from Zaithmel, 1999 as quoted by Lee 2004.

The above model shows that to assess the level of satisfaction with the service delivery one comparers users' expectations with his/her perception of the service delivered. This comparison leads to the identification of the perceived service quality gap on the five dimensions (see Table 1 below) of tangibles, reliability, responsiveness, assurance and empathy. Clearly from the framework, service quality is the disconfirmation between the customer's expectations and perception of service performance. 


\section{Measurement of service quality: the SERVQUAL instrument}

Measuring service quality is an important management activity, whose results can be used to offer products or services that delight customers. Many instruments have been developed to measure quality. For this study the instrument developed by Parasuramann (1988) was used with dimensions and indicators as shown in Table 1 below. The Parasuraman et al. (1988) model can be adapted to urban water delivery as shown in Table 1.

\section{Table 1: Water Service Quality model}

\begin{tabular}{|c|c|c|}
\hline Dimension & Description & Indicators \\
\hline Reliability & $\begin{array}{l}\text { Ability to deliver water } \\
\text { dependably and } \\
\text { accurately. }\end{array}$ & $\begin{array}{l}\text { Living to the promises made, showing } \\
\text { sincere interest in solving customer's } \\
\text { problems, providing water at the promised } \\
\text { time, ensuring billing accuracy, ensuring } \\
\text { few water interruptions }\end{array}$ \\
\hline $\begin{array}{l}\text { Tangibles } \\
\text { (service } \\
\text { environment) }\end{array}$ & $\begin{array}{l}\text { Appearance of physical } \\
\text { facilities, equipment, } \\
\text { personnel and } \\
\text { communication materials. }\end{array}$ & $\begin{array}{l}\text { Up-to-date equipment, visibly appealing } \\
\text { facilities, employees that are well dressed } \\
\text { and appear neat, water pipes that are well } \\
\text { maintained }\end{array}$ \\
\hline Responsiveness & $\begin{array}{l}\text { Willingness to help } \\
\text { customers and provide } \\
\text { prompt service. }\end{array}$ & $\begin{array}{l}\text { Customers given individual attention, } \\
\text { identifying customer's needs, having } \\
\text { customers' interests at heart, prompt } \\
\text { handling of complaints }\end{array}$ \\
\hline Assurance & $\begin{array}{l}\text { Knowledge and courtesy } \\
\text { of employees and their } \\
\text { ability to convey trust and } \\
\text { confidence. }\end{array}$ & $\begin{array}{l}\text { Customers trusting employees, customers } \\
\text { considering water to be safe, employees } \\
\text { being polite employees having knowledge } \\
\text { to address customer's questions. }\end{array}$ \\
\hline Empathy & $\begin{array}{l}\text { Caring, individualized } \\
\text { attention provided to the } \\
\text { customer. }\end{array}$ & $\begin{array}{l}\text { Timely information on likely water } \\
\text { disconnection, adequate time given for } \\
\text { water bill clearance, length of queues } \\
\text { while clearing water bills, willingness of } \\
\text { employees to help }\end{array}$ \\
\hline
\end{tabular}

Source: Parasuraman et al. (1988); Parasuraman and Berry, (2002), Tynan and Kingdom 2002

The service quality (Q) $\triangle \quad$ depends on the capability to minimize the gap between expected quality (Qe) and Perceived Quality (Qp) b $\Delta$ customers:

$$
\mathbf{Q}=\mathbf{Q p}-\mathbf{Q e}
$$

The above expression can be used for each service quality dimension and or for the overall service quality. When expected service exceeds perceived service (negative gap score), quality is unsatisfactory. The bigger the negative gap scores the higher the level of unsatisfactory performance. When expected service equals perceived service (zero gap score) quality is satisfactory. When perceived service exceeds expected service (positive gap score) then service level is more than satisfactory. Parasuraman et al. 1988; Foster, 2004; and Walter, 2006; contend that if the service provided by the organization does meet the needs and expectations of the customer, then this may subsequently lead to higher customer satisfaction. 
The SERVQUAL instrument is accepted as a valid and reliable instrument. Its use allows investigation of service quality in a number of ways as highlighted by Donnelly and Shiu (1999): the customers' ratings of service quality dimensions and their importance can be assessed to provide information on service provider's performance; the impact of service provider's action on service quality can be monitored over time; and the gaps in meeting customer expectations can be indentified and quantified to support better prioritization in developing service improvement.

Many studies have applied the SERVQUAL mode in different industries, for instance retailing (Oliver, 1981), education (Cuthbert, 1996), health (Lam, 1997), airlines (Robledo 2001) and banking (Newman, 2001), and tourism (Akam and Kieti, 2003), among others. Few studies have applied the model in the water sector (Lee, 2004).

\section{Criticisms of the SERVQUAL Instrument}

Although widely used, the instrument is subject to a number of criticisms (Carman, 2000; Babakus and Boller, 1992; Cronin and Taylor 1992; Teas 1993; and Chase and Stewart, 1994). The critics have focused on the operatisation of perceived quality as a gap score, the ambiguities of the expectation construct and the unsuitability across different services.

Carman (2000) questions the validity of the expectations measure when consumers do not have well-formed expectations and suggest that the dimensions in SERVQUAL are not generic well informed.

Babakus and Boller (1992) question the dimensionality of the instrument arguing that the dimensionality of service quality depends on the type of industry being studied. They claim that measures designed for specific industries are more appropriate than SERVQUAL.

Cronin and Taylor (1992) argue that service quality is a form of consumer attitude and measuring service quality using SERVQUAL on a performance minus expectation basis is inappropriate. After studying service quality in four industries (banking, pest control, dry cleaning and fast food), they propose a performance based measure of performance called SERVPERF as an enhanced means of measuring service quality. This SERVPERF measure is based essentially on consumers' perceptions of actual performance. It consists of only the 22 features on the SERVQUAL scale without consideration of expectations.

Parasaraman et al., (1991) responds to critics by quoting several studies that have applied the model and concluded that it is a reliable instrument. On whether service quality should be measured using the SERVQUAL or SERVPERF, Zeithamal et al. (1996) recommended that if the primary purpose of measuring service quality is to explain the variance in the dependent construct, SERVPERF is appropriate. On the other hand if the purpose is to diagnose service shortfalls, the SERVQUAL is suitable.

The weaknesses notwithstanding, SERVQUAL still seems to be the most practical method available for measuring service quality (Cuthbert, 1996). There is general consensus that the 22 features of the SERVQUAL are reasonably good predictors of service quality.

\section{Approach and Method}

Two typical cases of urban water utilities that have adopted NPM reforms in the great lakes region of Africa were selected. NWSC was also selected because it is being referred to as a high performing water utility in Sub-Saharan Africa (Schwartz, 1999; Muhairwe, 
2009). In contrast DAWASA / DAWASCO is commonly identified as a below average performing water utility (Mujwahuzi, 2002; Kjellen, 2006; Kiwanga, 2008). We adopted a three - step approach to the analysis of findings as shown in Figure 3.

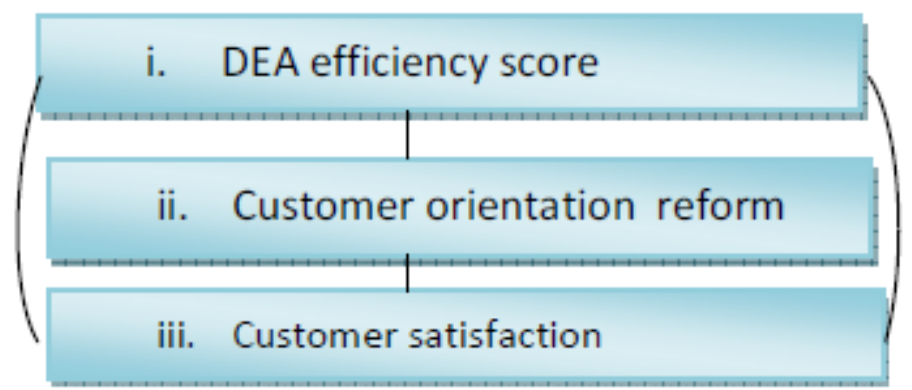

Figure 3: A three-step approach to data analysis

\section{i. DEA Efficiency Score}

We used DEA to calculate the technical efficiency of the different DMUs. DEA calculates the relative efficiency of each DMU compared to other DMUs by using actual observed values for the inputs and outputs of each DMU. It also identifies the sources and level of inefficiency for each input and output (Charnes et al. 1978). Given a collection of $j=$ $1,2,3, \ldots, \mathrm{n}$ DMUs, DEA attempts to maximize the ratio of outputs $\mathrm{y}$ to inputs $\mathrm{x}$ by attaching weights in order to assess each DMU relative to similar DMUs.

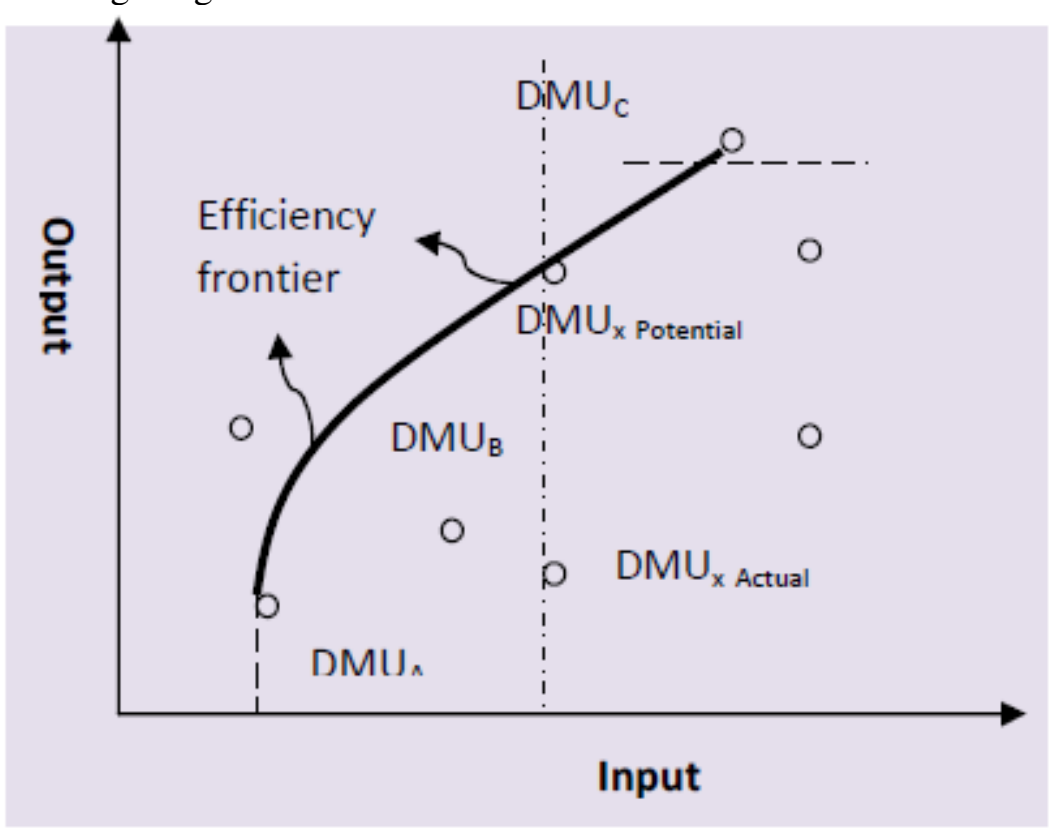

Figure 4: Data Envelopment Analysis

In Figure 4, DMUs A, B, and C together define the efficiency frontier. By contrast, $\mathrm{DMU}_{\mathrm{x}}$ clearly lies inside this frontier and its vertical distance $\left(\mathrm{DMU}_{\mathrm{x}}\right.$ (potential) and $\mathrm{DMU}_{\mathrm{x}}$ (actual) can be used to calculate its efficiency. $\mathrm{DMU}_{\mathrm{s}} \mathrm{B}$ and $\mathrm{C}$ provide a reference 'peer group' that can be used to set output maximization or input minimisation for $\mathrm{x}$. 
Initially we calculated the technical efficiency scores for 30 DMUs (18 for NWSC and 12 for DAWASCO) using DEA. Measuring efficiency in this manner is consistent with both literature associated with the efficiency measurement of water service providers such as Moore 1994, and Dewittee 2008 and with past empirical approaches to efficiency measurement in the water sector notably, Thanassoulis 2000, Kirkpatrick et al. 2006 and Mugisha 2007.

Banker et al. 1984 suggests that as a way of balancing between the degrees of freedom and sample size; there should be three DMUs for every variable to ensure meaningful analysis. If $\mathrm{x}$ is the number of inputs and $\mathrm{y}$ the number of outputs, then the sample $\mathrm{n}$ should satisfy $n \geq 3(x+y)$. For this study we chose one input and two outputs $n \geq 9$; as shown in Table 2.

Table 2: The DEA model used

\begin{tabular}{ll}
\hline Input & Outputs \\
\hline Operating Expenses & $\begin{array}{l}\text { Volume of water billed } \\
\text { Non Revenue Water }\end{array}$ \\
\hline
\end{tabular}

There are two DEA model orientations; input and output orientation. The input orientation emphasizes input reduction to achieve a particular level of output. On the other hand, output orientation considers achieving more output with the present level of inputs. In this study we use output orientation because both corporations are public utilities and the arrangement between $\mathrm{HO}$ and DMUs is for the latter to maximize outputs given a particular level of inputs. Besides this, the water coverage in these areas is below $75 \%$ and Non Revenue Water is above 35\%, hence increasing the amount of water billed is a key objective.

According to Charnes et al. 1978 and Banker et al. 1984, DEA orientation based on scale economies has two dimensions, variable and constant returns to scale. If one assumes that scale economies remain fixed even when the level of service delivery increases, then Constant Returns to Scale (CRS) type of DEA models is an appropriate choice. Conversely, if it is assumed that scale economies vary with the level of service delivery then Variable Returns to Scale (VRS) as developed by Banker et al. 1984 would be desirable. In this study the different DMUs vary in terms of water billed, number of staff, and length of pipe network, hence we have chosen to use VRS because of the possibility of calculating technical efficiencies as different from scale efficiencies.

\section{ii. Customer Orientation}

To assess the DMUs' level of customer orientation we have based on the conceptualization of the concept by Jaworsk and Kohli (1993) as involving intelligence generation, intelligence dissemination and organizational wise responsiveness. Table 3 shows the specific attributes used.

Table 3: Attributes for assessing customer orientation

- Availability of customer care desk

- Availability of customer complaints management system

- Having periodic customer surveys

- Availability of guidelines for staff / customer interface

- Speed of response to customer inquiries 


\section{iii. Customer Satisfaction}

Using a SERQUAL questionnaire, responses from 599 customers of NWSC and DAWASCO were received out of 809 that were given out. The sample selected was based on guidance from Long and McMellon (2004) that the sample size should be at least 5 times the number of items.

The questionnaire was structured in two parts. Part one comprised of 22 features each grouped under five dimensions for evaluating expectations and perceptions respectively. This was done by respondents being asked to indicate their opinions of each feature on seven-point Likert scales anchored by "strongly disagree" (scale value of 1) and "strongly agree" (scale value of 7). The use of the seven-point Likert scale has been criticized for its lack of labelling for points two to six, resulting in a tendency of overusing the extreme ends of the scale by respondents (Lewis,1993). In this study a seven point scale as used in Parasuraman's et al. (1988) original study was adopted. The scales have been labelled as follows; 1 = strongly disagree; $2=$ Disagree; $3=$ Somewhat disagree; $4=$ Neither agree nor disagree; $5=$ Somewhat agree; $6=$ Agree; $7=$ Strongly agree.

\section{The DMUs used}

We have used the Decision Making Unit (DMU) of NWSC and DAWASCO as units of analysis. Data for 18 DMUs out of 23 from NWSC and 12 out of 13 from DAWASCO have been used. Some DMUs were left out due to incomplete data. Table 4 shows some of the characteristics of the DMUs of NWSC and DAWASCO in terms of volume of water produced and number of connections.

Table 4: Characteristics of DMUs in 2010

\begin{tabular}{llllll}
\hline $\begin{array}{l}\text { NWSC } \\
\text { Area }\end{array}$ & $\begin{array}{l}\text { Volume of water } \\
\text { produced } \mathbf{( m}^{3} \text {, } \\
\text { day) }\end{array}$ & $\begin{array}{l}\text { No. of } \\
\text { connections }\end{array}$ & $\begin{array}{l}\text { DAWASCO } \\
\text { Area }\end{array}$ & $\begin{array}{l}\text { Volume of water } \\
\text { produced } \mathbf{( m}^{3} \text {, } \\
\text { day) }\end{array}$ & $\begin{array}{l}\text { No. of } \\
\text { connections }\end{array}$ \\
\hline Kampala & 142,097 & 133,198 & Gerezani & 2,575 & 1,312 \\
Jinja & 12,559 & 15,727 & llala & 961 & 5,239 \\
Entebbe & 7,064 & 14,574 & Kinondoni & 1,687 & 10,924 \\
Tororo & 2,107 & 3,354 & Magomeni & 1,067 & 9,810 \\
Mbale & 3,670 & 6,885 & Kawe & 1,149 & 9,051 \\
Mbarara & 6,511 & 8,885 & Temeke & 513 & 5,034 \\
Masaka & 3,228 & 5,836 & Bagamoyo & 202 & 2,124 \\
Lira & 2,604 & 5,337 & Kibaha & 855 & 5,779 \\
Gulu & 2,368 & 3,828 & Mlandizi & 146 & 1,371 \\
Kasese & 1,751 & 3,652 & Boko & 1,121 & 7,602 \\
Fortportal & 1,902 & 3,993 & City centre & 1,431 & 5,138 \\
Kabale & 1,432 & 3,523 & Kimara & 508 & 2,040 \\
Arua & 1,665 & 4,358 & Tabata & 122 & \\
Soroti & 1,958 & 3,962 & & & \\
Hoima & 1,037 & 2,849 & & & \\
Masindi & 1,267 & 2,542 & & & \\
Mubende & 1,013 & 1,825 & & & \\
Bushenyi & 644 & 1,604 & & & \\
\hline
\end{tabular}

Source: NWSC (2010); DAWASCO (2010) 


\section{Findings and Discussion}

In this section we present our findings of the 30 DMUs on the level of customer orientation, technical efficiency, and customer satisfaction. Table 5 below shows the minimum, maximum, mean and standard deviation of the three variables.

Table 5: Efficiency, Service Quality and Customer Orientation

\begin{tabular}{llllll}
\hline & $\mathrm{N}$ & Minimum & Maximum & Mean & Std. Deviation \\
\hline DEA Efficiency score & 30 & 25.90 & 100.00 & 84.1067 & 24.14601 \\
Service quality Gap score & 30 & .31 & 4.05 & 2.3263 & .89453 \\
Customer orientation level & 30 & 32.00 & 99.00 & 74.2667 & 19.66606 \\
\hline
\end{tabular}

\section{Level of Customer Orientation}

A combination of what we observed in terms of front desk layout and appearance, attitude and behaviour of staff interfacing with customers, plus results of interviews with management and staff that interface with customers has made us conclude that there are variations on the level of customer orientation between DMUs, despite similarity in the corporate strategies adopted. For example in one DMU a manager talking to a customer in the next office said: "you are the reason we exist; I cannot delay that connection; we are going to act immediately". The friendly front desk officers, the writings are clear on the wall that the corporation lives up to its slogan; "the customer, the reason we exist." In an interview with one of the managers in NWSC HO, he commented that: "With generous donor support, all NWSC programmes and activities have revolved around customer happiness, contentment and satisfaction with the services offered".

Our findings on customer orientation show an average score for the 30 DMUs of $74 \%$. The mean score for the DMUs of NWSC is $87.5 \%$ while for those of DAWASCO the score is $54.4 \%$. This implies that the DMUs of NWSC are high on adopting customer orientation reform than their counter parts of in DAWASCO.

Interviews with management of DAWASCO indicated in most DMUs the relationship between the corporation and its customers was characterized by distrust, hostility and disgust. Response to customer requests and complaints was usually slow and inadequate. The customers were bitter with incessant water supply interruptions, water disconnection without notice, poor response to leaks and busts, inaccurate bills, belated billing and bill delivery, poor customer care, lack of professionalism, dishonesty, and corruption, lack of proper field staff identification, staff rudeness, indifference and insensitivity. It was common practice that for a customer to get a new connection staff had to be bribed. Indeed one manager commented; "at times we deal with shameless thieves who are selfserving and believe that they do customers a favour to avail them with water yet they had to pay for it".

The workers on the other hand were blaming customers for illegal connections, meter defilement, vandalism and theft, bribery and corruption, harassment of field staff and refusal to pay bills. In some cases where the relations were seen to be good, it was for personal gain of the individuals concerned at the expense of the corporation. A manager illustrated this by saying: "it was common for customers to collude with staff of the corporation to carryout illicit activities like illegal connections, meter bypasses, damaged meters and data manipulation among others". In Figure 5 we summarise the adversarial relationship between water utility staff and its customers. 


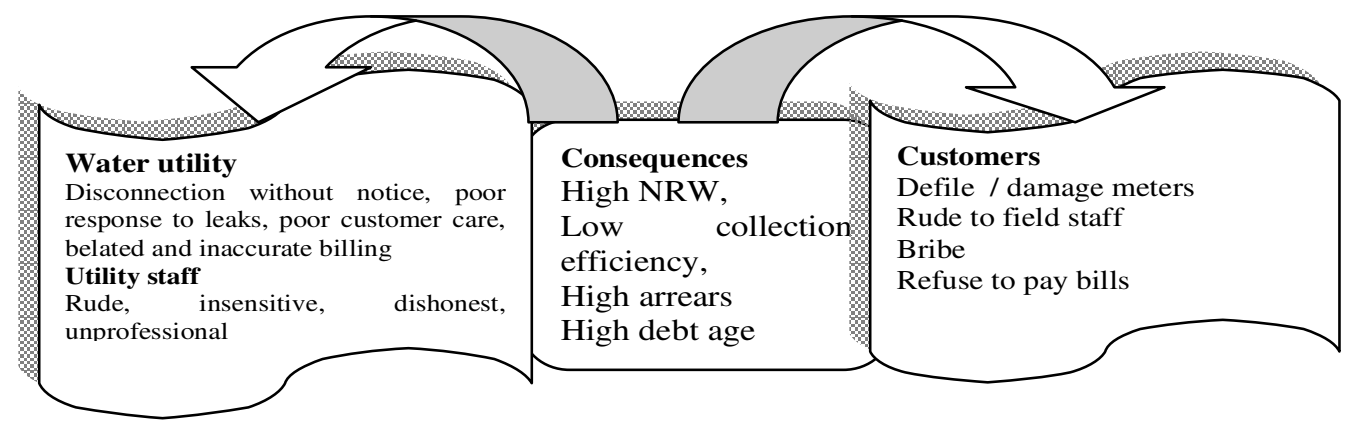

\section{Figure 5: Adversarial relationship between utility staff and customers}

The move now in all DMUs is towards developing a customer oriented utility with a partnership interface between the customer and the utility as illustrated in Figure 6 below.

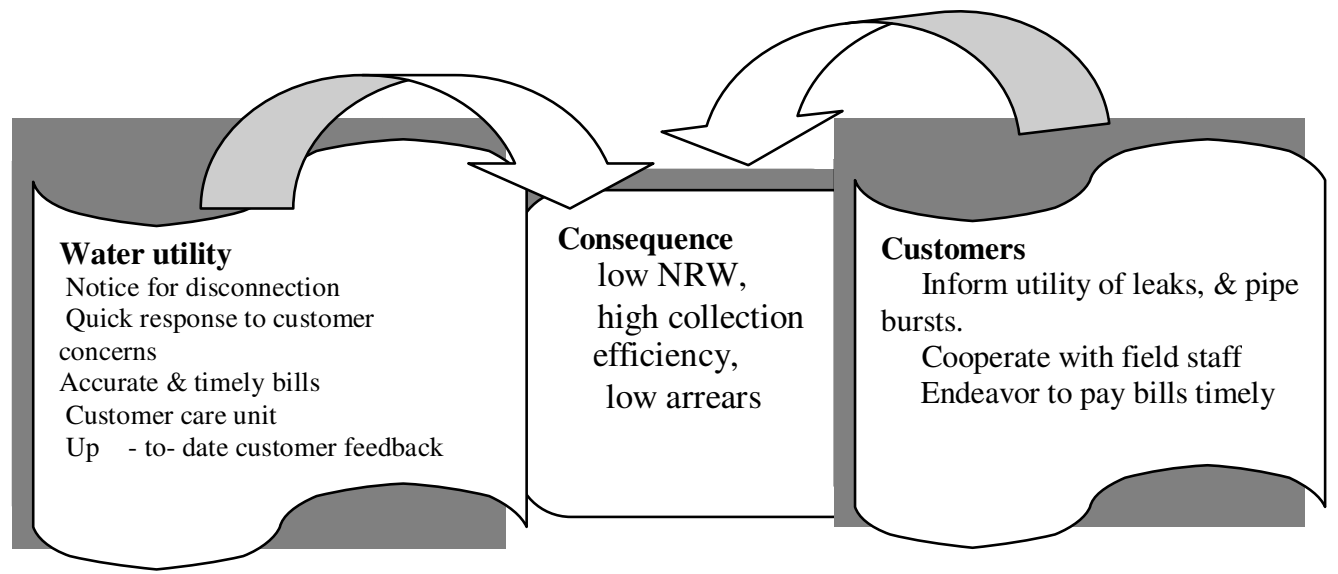

Figure 6: A Customer Oriented DMU

Interviews held with management of the different DMUs indicated the following as strategies adopted to have customer oriented approaches:

\section{Developing Customer-Oriented Staff}

The important thing was to change the work ethic and customer care attitudes of staff. This first thing was to sensitize staff about the reason for the utility's existence and that their jobs and livelihood depended on customer satisfaction and willingness to pay. Customers were sensitized on the merits and modalities of customer care. Field staff were given identifications and demanded that they behave politely towards customers. Staff members were duty bound to respond promptly to customer queries, complaints, and reports. Staff members are supposed to communicate attentively and with a smile. Tailormade training programmes targeting all staff that interface directly with customers were conducted. The staff involved in the training included commercial officers, meter readers, front desk staff, cashiers, and plumbers among others. 


\section{Instituting Customer Oriented Policies}

A customer care policy was developed to address the concerns and aspirations of customers. Customers were publicly (through print and electronic media) sensitized about their rights and responsibilities. It was emphasized that customers deserved and were entitled to prompt and efficient services and they had the right to demand information regarding all aspects of water production, distribution, pricing and accessibility. Illegal water customers who voluntarily reported themselves were granted amnesty to regularize their connections.

Customers with huge arrears or suppressed accounts were invited to negotiate payment in affordable instalments. Defaulters were offered to reconnect water without pay. Bad debts were also written off. Customers were visited on a regular basis and some were invited to the corporate functions. Customer centres and units were set up throughout the corporation to open up communication channels. Also well trained research assistants to sit in the front desk offices and track customers entering and leaving customer service centres were established. The independent research assistants would interrogate the customers in a cordial manner with the intention of capturing their residual grievances and checking whether they have been assisted. The findings of the research assistants are discussed by the DMU managers who would compile daily reports incorporating the agreed way forward with the managers. The DMU managers are expected to take action in a timely manner and give feedback to responsible people at HO.

\section{Periodic Customer Surveys}

These emerged from the need to conduct an independent assessment of customer perceptions of the corporation's water services. The main objectives of these surveys included determining the overall customer satisfaction with NWSC's services and identifying customer perceived areas of strength that needed to be enhanced and consolidated, as well as areas of weaknesses that desired attention for continuous service delivery in a sustainable way. Another objective was to develop a tool to measure how increased customer satisfaction impacts on repeat sales. The customer satisfaction parameters used include response time to bills, billing accuracy, payment convenience, staff-customer efficiency and rapport, water quality, water quantity, adequacy and regularity, service coverage and response time to customer complaints.

\section{Using results from Customer Surveys and Feedback}

Information is commonly got from customer surveys, suggestion boxes, customer care centres, interactions with customers and media comments from customers. The nature and content of customer complaints, comments, and suggestions is studied to identify the appropriate course of action. The course of action depends on the source and nature of information. The customer information collected is passed on to the relevant departments for action. Managers and staff respond to issues pertaining to their jurisdiction with a sense of urgency and professionalism.

\section{Customer Care Sections}

In all DMU, customer care sections were created. These areas were equipped with new furniture and customer care registers were opened to record all customer complaints and the actions taken. The ambience of customer care offices was also emphasized especially 
in the DMUs of NWSC and this included cleanliness, smartness, tidiness and general attractiveness.

\section{Customer's Payment Options}

Flexibility in the water payment system was also considered. A clear signal was sent to all customers that the corporation is flexible and ready to listen. Convenient payment schedules were drawn for customers who had huge arrears. In terms of convenience, customers who could not pay at the corporation's offices were given an option of settling their bills directly through banks. For customers with mobile phones, arrangements were made for them to access their account balances through SMS facility and pay to the nearest cash office or bank ATM. Direct debit systems were also introduced.

\section{Decentralizing functions to branches for quick response to customers}

A decision was taken to decentralize most customer related functions to the areas to make service delivery to the customers more efficient. The objective was to give areas the opportunity to be more creative and to design strategies that were suitable for their own local environment. The decentralized functions included billing, revenue collection, and response to customer inquiries.

\section{Technical Efficiency}

The mean DEA efficiency score for the all the DMUs was 84 while that for the DMUs of NWSC was 93 and DAWASCO 71. Using the efficiency scores and differentiating fully efficient towns basing on the number of benchmarks as suggested by Anwandter and Ozuna, (2002), the towns have been ranked on a scale of 1(highly efficient) to 18 (least efficient) for NWSC and up to 12 (least efficient) for DAWASCO as indicated in Table 6.

Table 6 Efficiency Clusters of DMUs

\begin{tabular}{|c|c|c|c|c|c|}
\hline \multirow{2}{*}{$\begin{array}{l}\text { Highly efficient } \\
D M U\end{array}$} & \multirow[b]{2}{*}{ Rank } & \multicolumn{2}{|c|}{ Moderately efficient } & \multicolumn{2}{|c|}{ Least efficient } \\
\hline & & $D M U$ & Rank & $D M U$ & Rank \\
\hline \multicolumn{6}{|l|}{ NWSC } \\
\hline Entebbe & 1 & Hoima & 7 & Masaka & 13 \\
\hline Kampala & 2 & Gulu & 8 & Mbale & 14 \\
\hline Mubende & 3 & Jinja & 9 & Tororo & 15 \\
\hline Masindi & 4 & Lira & 10 & Kabale & 16 \\
\hline Fortportal & 5 & Kasese & 11 & Bushenyi & 17 \\
\hline \multicolumn{5}{|l|}{ DAWASCO } & 18 \\
\hline Gerezani & 1 & Kibaha & 5 & Bagamoyo & 9 \\
\hline City Centre & 2 & Magomeni & 6 & Ilala & 10 \\
\hline Kinondoni & 3 & Kawe & 7 & Kimara & 11 \\
\hline Boko & 4 & Kisutu & 8 & Temeke & 12 \\
\hline
\end{tabular}

\section{Efficiency Clusters for NWSC}

Two (Entebbe and Fort portal) of the top highly efficient towns have been under the jurisdiction of NWSC way before the year 2000. The other three, Kampala, Mubende, and Masindi were initially managed by private operators. Still in the highly efficient category apart from Mubende and Masindi, the rest were constituted into partnerships Greater Entebbe water Partnership for Entebbe, Rwenzori Water partnership for Fortportal and 
Kampala Water Partnership since the year 2009. Another attribute that can be considered for this cluster is the profitability performance. The financial statements for the year ending June 2009 indicate that Kampala was the most profitable segment followed by Entebbe. However, using the NRW performance indicator, Kampala had the highest score of $42.9 \%$ while Entebbe had a score of $15.8 \%$.

In the least efficient category Soroti was initially managed by private operators while the rest have been under NWSC jurisdiction. In this category, it is only Mbale that has been constituted into a partnership known as Elgon water partnership. Using the profitability indicator for the year ended June 2009, Soroti, Bushenyi, and Kabale were loss making DMUs, though their NRW scores were $21.2 \%, 17.8 \%$ and $9.3 \%$ respectively. The other towns in this cluster their performance is average.

\section{Efficiency Clusters for DAWASCO}

Considering the clusters for DAWASCO, the highly efficient cluster is composed of DMUs like Gerezani, City centre, and Boko. These are averagely planned settlements. According to the Water Aid Report, 2003, a sizeable number of residents in these areas are connected to the DAWASCO water network. In contrast the least efficient clusters especially the DMUs of Temeke and Ilala have unplanned settlements. According to Napacho and Mayele (2010) many of the residents are not connected to piped water. Indeed Water Aid (2003) gives a percentage of $8 \%$ of the residents in Temeke as those connected to DAWASCO water directly, $21 \%$ connect to DAWASCO through their neighbours. This offers a high chance of illegal connections, unmetered water and water theft. It is not surprising the in these areas that NRW scores range between $50 \%$ and $67 \%$.

\section{Customer Satisfaction}

The findings give the overall service quality scores as the gap between expected and perceived quality.

\section{Overall scores for expectations, perceptions and service quality gap}

The overall minimum, maximum, mean and standard deviation values for expectation, perception and service quality gap scores are given in the Table 7 below.

Table 7: Overall Scores for Expectations, Perceptions and Service Quality Gap

\begin{tabular}{lllllll}
\hline Variables & N & \multicolumn{3}{c}{ Mean } & & \multicolumn{2}{c}{ Standard Deviation } \\
\hline & NWSC & DAWASCO & NWSC & DAWASCO & NWSC & DAWASCO \\
Expectation & 391 & 208 & 6.72 & 6.43 & 0.17 & 0.46 \\
Perception & 391 & 208 & 4.74 & 3.62 & 0.96 & 0.54 \\
\hline
\end{tabular}

Overall mean service Quality gap Score: NWSC -1.98 ; $\quad$ DAWASCO -2.81

The mean score on a seven point scale for expectation was 6.72 and for perceptions 4.74 for NWSC giving a service quality gap score of -1.98. On the other hand, DAWASCO got a mean score of 6.43 for expectation and 3.62 on perception giving a service quality gap of -2.81. The negative service quality gap for both utilities indicates that NWSC's and DAWASCO's customers perceived the utility's performance to be below their expectations. It is logical and common to have negative service quality scores if expectations are considered ideal as it is in this case. This is so because it is unlikely for a water utility to consistently provide services that exceed all its customers' expectations. Lower negative scores indicate better service quality. The negative score of -1.98 for 
NWSC is reasonable however; the one of -2.81 for DAWASCO is an indicator of inadequate water quality service delivery. This is consistent with a conclusion drawn by Parasuraman et al. 1988 that a negative service quality gap score of above 2.5 is serious to warrant urgent managerial action to be taken to reduce the gap.

\section{Relationship between Customer Orientation, Efficiency and Customer Satisfaction}

Using SPSS version 16, we calculated the Pearson correlation coefficient between customer orientation, efficiency and customer satisfaction and the results are in Table 8.

Table 8: Customer Orientation, Efficiency and Customer Satisfaction

\begin{tabular}{lllll}
\hline & & DEA score & SEVQGAP & CUSORR \\
\hline DEA score & Pearson Correlation & 1 & -.163 & $.581^{\prime \prime}$ \\
& Sig. (2-tailed) & & .390 & .001 \\
& $\mathrm{~N}$ & 30 & 30 & 30 \\
SEVQGAP & Pearson Correlation & -.163 & 1 & $-.442^{\prime}$ \\
& Sig. (2-tailed) & .390 & & .014 \\
& $\mathrm{~N}$ & 30 & 30 & 30 \\
CUSORR & Pearson Correlation & $.581^{\circ}$ & -.442 & 1 \\
& Sig. (2-tailed) & .001 & .014 & \\
& $\mathrm{~N}$ & 30 & 30 & 30 \\
\hline
\end{tabular}

As shown in Table 3 the results indicate significant positive $(\mathrm{r}=0.581 ; \mathrm{p}<0.01)$ relationship between customer orientation and DEA efficiency score, a significant negative $(r=-0.442$, $\mathrm{p}<0.05$ ) between customer orientation and service quality gap score, and a negative, not statistically significant $(\mathrm{r}=-0.162, \mathrm{p}>0.05)$ relationship between efficiency and service quality gap score. This implies that as DMUs increase customer orientation levels, technical efficiency and the service quality gap improve. However, the negative relationship between efficiency and the service quality gap though statistically not significant implies that efficiency may improve as service quality improves since we are using the water service quality gaps where a small gap indicates high level of service quality and vice versa.

Apart from using correlations to assess the technical efficiency / customer satisfaction link, we run the DEA model with the service quality gap scores of the 30 DMUs and the results are summarized in Table 9.

Table 9: DEA scores with and without service quality gap scores

\begin{tabular}{lllll}
\hline Item & Min & Max & Mean & Std. Deviation \\
\hline DEA efficiency score & 25.90 & 100.00 & 84.12 & 24.15 \\
DEA efficiency score with Quality Gap scores & 31.10 & 100.00 & 80.29 & 23.95 \\
No. of DMUs & 30 & & & \\
\hline
\end{tabular}

Results in Table 9 show that when service quality gap scores are introduced in the DEA model as an output variable, the mean technical efficiency scores for the 30 DMUs reduces from 84.12 to 80.29 . Though the reduction is small, the results show that efficiency scores reduce when service quality gap scores are introduced into the model. The findings are in agreement with what Löthgren and Tambour (1999) found out that DEA efficiency scores reduce when customer satisfaction is introduced in the model. 


\section{Conclusion and Policy Implications}

With a view to improving water service delivery, NWSC and DAWASCO have embraced customer orientation reform. The DMUs of NWSC portray high levels of customer orientation than their counterparts in NWSC. Indeed a utility increases its adoption of customer orientation, technical efficiency and service quality and consequent customer satisfaction may improve.

NWSC is close to meeting its customer's expectations with a service quality gap of 1.98. DAWASCO on the other hand is comparatively far from meeting customer expectations with a service quality gap of -2.81 .

There are opposing views on the link between customer satisfaction and efficiency with some researchers concluding that the two are compatible while others state that the two conflict. Our conclusion is that efficiency may be sacrificed as a utility engages in activities to improve the level of customer satisfaction with service delivery. However, the trade-off between the two in NWSC and DAWASCO is statistically not significant. Thus by improving customer satisfaction the two utilities will not significantly reduce technical efficiency. This is in line with the conclusion by Luo and Homburg (2007) that there is no significant conflict between efficiency and customer satisfaction goals. We recommend reinforcement of the customer orientation reform in public water utilities in Uganda and Tanzania.

\section{References}

Awortwi, N., "Getting the Fundamentals Wrong: Governance of Multiple Modalities of Basic Services Delivery in Three Ghanaian Cities", PhD Thesis, (Institute of Social Studies, Shaker Publishing: Maastricht, 2003).

Babakus, E. and Boller, G.W. (1992). "An empirical assessment of the SERVQUAL scale", Journal of Business Research, Vol. 24, pp. 253-68.

Batley, R., The role of Government in Adjusting Economies: An Overview of Findings, (Birmingham International Development Department, University of Birmingham, 1999).

Benington, J., In Search of Public Value - Beyond Private Choice, (Palgrave, Coventry, 2007).

Bitner, M. J., Booms, B. H., and Mohr, L. A., Critical Service Encounters: The Employee Viewpoint. Journal of Marketing, 58, no.4, (1994), 95-106.

Bovaird, T., "Developing new forms of partnership with the 'Market' in the procurement of public services", Public Administration 76, no.4, (2006), 695-712.

Brady, M. K., and Robertson, C. J. (2001). "Searching for a consensus on the antecedent role of service quality and satisfaction: an exploratory cross-national study", Journal of Business Research, 51(1), 50-63.

Carman, J.M., (2000). "Patient perceptions of service quality: combining the dimensions". Journal of Services Marketing 14 (4), 337-352.

Charnes, A., Cooper, W., Rhodes, E., "Measuring the efficiency of decision making units", European Journal of Operational Research, Vol. 2, No.6, pp. 429-444, 1978.

Chase, R.B. and Stewart, D.M. (1994), "Make your service fail-safe", Sloan Management Review, 35 (3), 35 - 44. 
Cronin, J.J. and Taylor, S.A. (1992,) "Measuring service quality: a re-examination and extension", Journal of marketing, 56 (July), 55-68.

Cuthbert, P.F. (1996), "Managing service quality in HE: is SERVQUAL the answer? Part 1 and part 2" Managing Service Quality, 6, (2), 11-16 and 6, (3), 31-35.

DAWASCO, Annual Report (June, 2010).

Donnelly, M. and Shiu, E. (1999), "Assessing service quality and its link with value formerly in a UK local authority's housing repairs service using the SERVQUAL", Total Quality Management, 10 (4 \& 5), 498-506.

Dulaiman, M.F. "The challenge of customer orientation in the construction industry", Construction Innovation, 5, no.1, (2005), 3-12.

Environmental Health in East Africa. Tanzania Country Study. London, IIED, 2002.

Jaworsk, B. J., Kohli, A. K., "Market orientation: Antecedents and consequences," Journal of Marketing, 57, no.3, (1993), 53-70.

Kaplan, R.S., (2005). "How the balanced score card complements the Mckinsey 7-S model", Strategy and Leadership, 33(3), 41- 46.

Kaplan, R.S., "How the balanced score card complements the Mckinsey 7-S model", Strategy and Leadership, 33 no.3, (2005), 41- 46.

Kirkpatrick, C., Parker, D. and Zhang, Y. F. (2004). “An empirical analysis of state and private-sector provision of water services in Africa", The World Bank Economic Review, 20(1), 143-163.

Kiwanga,. "Evaluation of water supply and sanitation delivery services in Tanzania" World Water Week, Peer reviewed workshop; February, 2008.

Kjellen, M., (2006). "From Public Pipes to Private Hands, water access and Distribution on Dar es Salaam Tanzania", PhD Thesis; Stockholm University, Sweden.

Kjellen, M., "From Public Pipes to Private Hands, water access and Distribution on Dar es Salaam Tanzania", PhD Thesis; Stockholm University, Sweden, 2006.

Kohli A., K., and Jaworski B., J., Market orientation: the construct, research, propositions, and managerial implications. Journal of Marketing. 54, no.2, (1990), 1-18.

Kotler P., Strategic Marketing for Non-profit Organizations, (Prentice-Hall, Englewood Cliffs, New Jersey, 1987).

Lam, S.S.K. (1997). "SERVQUAL: a tool for measuring patient's opinions of hospital service quality in Hong Kong”, Total Quality Management, 8, (4), 145- 52.

Lee, Y. C. (2004) “An exploratory study of industrial customer's perceptions of service quality in a privatized water company in Malaysia" DBA Thesis, University of South Australia.

Lewis, B.R. (1993). "Service quality: recent developments in financial services", International Journal of Bank Marketing, 7, (5), 4-12.

Long M \& McMellon C (2004). "Exploring determinants of retail service quality on the internet", Journal of Service Marketing, 18(1), 78-90.

Löthgren M. and Tambour M., "Productivity and customer satisfaction in Swedish pharmacies: A DEA network model”; European Journal of Operational Research, 115, no.3, (1999), 449-458.

Luo X., and Homburg C., "Neglected Outcomes of Customer Satisfaction"; Journal of Marketing, 71, no.2, (2007), 133 - 149.

Moore, M. (1995). Creating Public Value: Strategic Management in Government. Cambridge, Massachusetts: Harvard University Press. 
Mugisha, S., (2007). "Effects of incentive applications on technical efficiencies: Empirical Stance Held", World Economic Forum, "Development - Driven Public -Private Partnerships in water".

Muhairwe, W. T., Making Public Enterprises Work: From Despair to Promise: A turn around account, IWA Publishing, London, 2009.

Mujwahuzi, M. R., Drawers of Water II. 30 Years of Change in Domestic Water Use \&

Mukokoma M.M.N., "Application and effectiveness of New Public Management in National Water and Sewerage Corporation", Journal of Science and Sustainable Development, Vol. 2 No.1, pp.61 - 67, 2009.

MWE - Ministry of Water, Lands and Environment, Water and Sanitation Sector performance report. GOU, 1998.

Ndandiko, C., Private provision of Public services in developing countries?, University of Twente, The Netherlands, 2010.

NWSC, Annual Activity Report July 2009 to June 2010. (NWSC, 2010).

OECD, Water partnerships: Striking a balance, 7 April, OECD Observer, (Paris, 2003).

Ogawa H., Tanattashi K., "Effect of NPM: Data Envelopment Analysis". Government Auditing Review 15 (2008).

Ogawa H., Tanattashi K., "Effect of NPM: Data Envelopment Analysis". Government Auditing Review Vol.15, March, 2008.

Oliver, R. L. (1981). "Measurement and Evaluation of Satisfaction Processes in Retail Settings." Journal of Retailing, 57(3), 25-48.

Parasuraman, A., Zeithaml, V. A., \& Berry, L. L. (1985). "A conceptual model of service quality and its implication for future research", Journal of Marketing, 49, Fall, 41-50.

Parasuraman, A., Zeithaml, V. A., \& Berry, L. L. (1988). "SERVQUAL: a multiple- item scale for measuring consumer perceptions of service quality", Journal of Retailing, 64(1), 12-40.

Perreault W., D., and McCarthy E., J., Basic Marketing, ( Irwin, Homewood, IL, 1990).

Shi, A., (2000). How Access to Urban Potable Water and Sewerage Connections Affects Child Mortality, World Bank Policy Research Paper, Washington: World Bank.

Slater, S. \& Narver, J., "Does Competitive Environment Moderate the Market Orientation - Performance Relationship?” Journal of Marketing 58, January. (1994) 46-55.

Teas, R.K. (1993). "Expectations, performance evaluation and customers' perceptions of quality", Journal of Marketing, 57 (4), 18-34.

Tynan, N. and Kingdom, W., Effective Water Service Provision, Second Draft, Washington D.C.: World Bank, 2002.

Van Dijk M. P., Managing Cities in Developing Countries; The theory and Practice of Urban Management, Edward Elgar, Northampton USA, 2006.

Water Aid, Water Aid Tanzania. (Water Aid Overseas Committee Paper 00/13, 2005).

Wilson, R. M. S. and Gilligan, C. (1997). Strategic Marketing Management Planning, Implementation and Control, Second Edition, Butter-worth and Heinemann.

Yap S.,F., and Kew M., L., "Service quality and customer satisfaction: Antecedents of Customer's re-patronage intentions; Sunway College Journal, 4, January, (2007), 5973.

Zeithaml, V.A., Berry, L. L., Parasuraman, A., (1996). "The behavioural consequences of service quality", Journal of Marketing 60 (April), 31-46.

Zeithaml, V.A., Berry, L.L., Parasuraman, A., "The behavioural consequences of service quality", Journal of Marketing 60, no.2, (1996), 31-46. 


\section{Author Biography}

Mukokoma M. M. N is a Senior Lecturer in the Faculty of Business Administration and Management, Uganda Martyrs University. She holds an M Phil, MBA, ACCA and CIPS. She is a professional accountant and a specialist in Public management. She has published several articles on service delivery in local governments, higher education and private hospitals. She has also published a book on the motivation dilemma in Uganda.

Ssemwogere E. is a Senior Lecturer and the Associate Dean in the Faculty of Business Administration and Management, Uganda Martyrs University. Formerly he headed the Department of Microfinance at Uganda Martyrs University. 